\title{
Financial Mechanisms of Foreign Economic Activity Regulation in Top Trading Countries
}

\author{
Valentyna Tropina \\ Department of Finance, Banking and \\ Insurance \\ Pereiaslav-Khmelnytskyi Hryhorii \\ Skovoroda State Pedagogical \\ University \\ Pereiaslav-Khmelnytskyi, Ukraine \\ tropina@ukr.net
}

\author{
Tetiana Rybakova \\ Department of Economics \\ Pereiaslav-Khmelnytskyi Hryhorii \\ Skovoroda State Pedagogical \\ University \\ Pereiaslav-Khmelnytskyi, Ukraine \\ taryb@ukr.net
}

\begin{abstract}
The subject of the study is the theoretical background, practical aspects and current state of using financial mechanisms of foreign economic activity regulation in the countries which are leading exporters and importers of goods and commercial services. The purpose of the work is to reveal patterns of using the elements of financial mechanism in foreign economic activity regulation of the world leading countries in international trade in the conditions of globalization and international economic integration. Methodology: system-structural approach, induction method, statistical method, method of logical analysis, method of comparative analysis, methods of observation and generalization. Results of the work. The article presents an analysis of financial methods and instruments used for state financial regulation of foreign economic activity in the countries leaders in international trade: the USA, the EU as a customs union, China, Japan, and South Korea. The functioning of financial mechanism of foreign economic activity regulation in these countries is shown, taking into account their integration priorities and involvement into the processes of economic globalization. The peculiarities of using certain financial methods in foreign economic activity regulation are identified, depending on the key objectives of the states in the field of foreign economic activity. The field of application of results. The investigation results can be used in the research dedicated to the problems of foreign economic activity, financial regulation, international trade and financial policy. They can also be used in educational process, especially in preparation of the relevant sections of textbooks and tutorials for courses "Finance", "Foreign Trade". Conclusions. Analyzing the methods of foreign economic activity regulation one can see that it is economic and financial methods that are preferred for using by countries in international trade, and it is quite consistent with WTO recommendations. Besides, the financial mechanisms used by countries for foreign trade regulation fit into the international context by harmonizing their national legislation with WTO norms. Among the financial methods of foreign trade regulation the tariff regulations are most comprehensively used and legally welldeveloped. Besides, financial, credit and tax methods of export stimulation are also used. The instruments of foreign economic activity regulation applied by the countries under analysis depend greatly on signing various trade agreements, integration priorities of the countries and global economic trends.
\end{abstract}

Keywords-foreign economic activity, regulations, international trade, financial mechanism, financial methods, tariff regulations.

\section{INTRODUCTION}

Participation of the countries with a market economy in the process of globalization needs the creation of an effective mechanism ensuring the maximum of international integration benefits and protecting the economy from the negative consequences of globalization. Nowadays each state regulates, stimulates or limits almost all spheres of international economic relations in any way. State regulation of foreign economic activity is a set of forms, methods and instruments used by government bodies to influence economic relations between countries in accordance with state and national interests, goals, and objectives.

Such regulation in developed countries is implemented to international trade in goods and services (trade regulation), as well as to international factor movements (migration processes, movement of capital, direct foreign investments) and scientific and technical cooperation.

Realization of the task of optimal state regulation of economic processes should be applied, first of all, by means and methods of financial policy, which is one of the main components of economic policy nowadays. The importance of studying the financial mechanisms of foreign economic activity regulation is based on the fact that it is financial levers that ultimately determine its results and efficiency. Most of the effects influencing business entities activities are realized by means of financial regulation mechanisms.

The financial mechanism of foreign economic activity is a multilevel system of financial relations between economic entities conducting foreign economic activity in conditions of world economy globalization and enterprises internationalization.

Modern scientists point to the need for developing and substantiating the foreign economic activity financial regulation as a system where the influence of the external environment represented by a global financial market is significant. The structure of such a system at the macro level should include the methods, forms, instruments and levers combined with the mechanisms of customs-tariff, monetary, foreign exchange, tax, insurance, budget regulation.

Analysis of recent research and publications. In modern scientific literature on finance the issues of functioning of the financial mechanism and financial regulation are covered quite sufficiently. The study of the financial mechanism structure and financial regulation as its part in the framework 
of the theory of finance was carried by such prominent Ukrainian scientists as M. Artus, V. Bazylevych, O. Vasylyk, O. Kyrylenko, O. Kovaliuk, S. Londar, S. Lovochkin, V. Oparin, V. Ospishchev, A. Poddierohin, V. Fedosov, I. Chuhunov, S. Yurii and others. Methods and problems of foreign economic activity state regulation are covered in the works of L. Antoniuk, I. Burakovskyi, A. Halchynskyi, O. Hrebelnyk, M. Didkivskyi, Ya.Zhalilo, A. Filipenko, Yu. Kozak, Yu. Makohon, V. Novytskyi and other wellknown domestic scientists studying foreign economic activity. Financial aspects of foreign economic activity regulation are investigated by scientists in the field of its tariff regulation (O. Hrebelnyk, T. Melnyk, O. Kuzmin, L. Pismachenko, P. Pashko, D. Pryimachenko), currency regulation (O. Bereslavska, O. Dziubliuk, V. Mishchenko, V. Yushchenko), financial regulation of business entities foreign economic activity (V. Vasiurenko, V. Matskiv, V. Plastun).

In the world economic science the issuers of foreign economic activity regulation are studied mainly via foreign trade policy research. Thus, in the works of J. Brander, E. Helpman, A. Hillman, R. Howse, P. Krugman, A. Krueger, D. Rodrik, F. Rodriguez, M. Trebilcock and other well-known authors the economic and financial instruments of foreign trade policy, the peculiarities of their application in the practice of developed trading countries and implementation in accordance with the norms of international organizations are analyzed in detail.

The unsolved research problem. Studying financial mechanisms of foreign economic activity regulation is a relatively new area of research in Ukraine; it is interesting due to the intensification of the processes of Ukraine's integration into the system of world economic relations. At the same time, domestic researchers mostly focus on economic regulation mechanisms in general, paying less attention to the functioning of the financial mechanism in the sphere of foreign economic activity. The latter in the conditions of high level of the economy openness is crucial for country development. The current economic situation in Ukraine is characterized by market relations development, further integration into the system of world labor division, dependence on world economic environment fluctuations, in particular financial crises and changes in foreign trade policy of key players. Therefore it is necessary to study in more detail the experience of foreign countries in the application of financial mechanisms for regulating foreign economic activity.

The purpose of the paper is to reveal patterns of using the elements of financial mechanism in foreign economic activity regulation of the world leading countries in international trade in the conditions of globalization and international economic integration.

\section{THE MAIN RESEARCH MATERIAL}

\section{A. Top Exporters Ranking}

On the basis of WTO statistics [1, p. 125-126] the volumes of international trade in goods and commercial services by countries were analyzed. The ranking of top exporters and importers in world merchandise trade and commercial services is presented in the Table 1 .
TABLE I. RANKING OF TOP EXPORTERS AND IMPORTERS IN WORLD MERCHANDISE TRADE AND COMMERCIAL SERVICES (EXCLUDING INTRA-EU (28) TRADE) IN 2017 (BILLION USD)

\begin{tabular}{|c|l|l|l|l|l|l|l|l|}
\hline $\begin{array}{c}\mathbf{R} \\
\mathbf{a n} \\
\mathbf{k}\end{array}$ & $\begin{array}{c}\text { Countr } \\
\mathbf{y}\end{array}$ & $\begin{array}{c}\text { expo } \\
\boldsymbol{r t}\end{array}$ & $\begin{array}{c}\text { impo } \\
\boldsymbol{r t}\end{array}$ & total & $\begin{array}{c}\text { Merpo } \\
\boldsymbol{r t}\end{array}$ & $\begin{array}{c}\text { impo } \\
\boldsymbol{r t}\end{array}$ & $\begin{array}{c}\text { Total } \\
\text { inter } \\
\text { natio } \\
\text { nal } \\
\text { trade }\end{array}$ \\
\hline 1 & $\begin{array}{l}\text { Extra- } \\
\text { EU(28) }\end{array}$ & 2122 & 2097 & 4219 & 1009 & 800 & 1809 & 6028 \\
\hline 2 & $\begin{array}{l}\text { United } \\
\text { States of } \\
\text { America }\end{array}$ & 1547 & 2410 & 3957 & 762 & 516 & 1278 & 5235 \\
\hline 3 & China & 2263 & 1842 & 4105 & 226 & 464 & 690 & 4795 \\
\hline 4 & Japan & 698 & 672 & 1370 & 180 & 189 & 369 & 1739 \\
\hline 5 & $\begin{array}{l}\text { Hong } \\
\text { Kong }\end{array}$ & 550 & 590 & 1140 & 104 & 77 & 181 & 1321 \\
\hline 6 & $\begin{array}{l}\text { Korea, } \\
\text { Republi } \\
\text { c of }\end{array}$ & 574 & 478 & 1052 & 86 & 120 & 206 & 1258 \\
\hline 7 & India & 298 & 447 & 745 & 183 & 153 & 336 & 1081 \\
\hline 8 & Canada & 421 & 442 & 863 & 86 & 105 & 191 & 1054 \\
\hline 9 & $\begin{array}{l}\text { Singapo } \\
\text { re }\end{array}$ & 373 & 328 & 701 & 164 & 171 & 335 & 1036 \\
\hline 10 & Mexico & 409 & 432 & 841 & 27 & 37 & 64 & 905 \\
\hline 11 & $\begin{array}{l}\text { Switzerl } \\
\text { and }\end{array}$ & 300 & 269 & 569 & 119 & 101 & 220 & 789 \\
\hline 12 & $\begin{array}{l}\text { United } \\
\text { Arab } \\
\text { Emirates }\end{array}$ & 360 & 268 & 628 & 70 & 84 & 154 & 782 \\
\hline 13 & $\begin{array}{l}\text { Russian } \\
\text { Federati } \\
\text { on }\end{array}$ & 353 & 238 & 591 & 57 & 87 & 144 & 735 \\
\hline & & & & & & & & \\
\hline
\end{tabular}

The industrially developed countries with the largest volumes of international trade in goods and commercial services were under analysis: the EU as a custom union, the United States, China, Japan and South Korea (Hong Kong as a Special Administrative Region of the People's Republic of China was not analyzed).

\section{B. Tariff Regulations}

Customs and tariff methods are the basis of foreign trade regulation. In the aspect of foreign economic activity financial regulation they should be considered as financial methods, since there is a direct link between customs tariff and pricing which is one of the financial methods in the structure of financial mechanism. Customs duty as an important element of customs and tariff regulation performs a fiscal function, thus is can be considered as a classic instrument of state financial policy.

European Union. The modern EU is an economic union, in particular a Customs Union according to the Article 3 of the Treaty on the Functioning of the European Union [2, p. 51] which comprises 28 countries (the UK will continue to be a part of the EU Customs Union internal market until the end of 2020). The EU Customs Union activity is harmonized with the GATT / WTO norms. Within the customs union on EU domestic market the Member States refuse from charging customs duties between each other (goods circulate freely between EU member states) and establish a common external tariff for goods from "third" (non-EU) countries. The trade with third countries is carried out in accordance with the EU Customs Code.

An important component of EU customs regulation is the Common Customs Tariff applicable to the import of goods 
across the EU external borders. This Tariff is a certain set of laws including tariff measures (combined nomenclature, tariff rates, tariff preferences, tariff quotas, suspensions of duties), agricultural measures, foreign trade defense instruments (antidumping duties and countervailing duties), non-tariff measures [3]. On its basis the integrated Tariff of the European Customs (TARIC) is formed. TARIC is an online tariff base that ensures the unification of tariffs use by all EU Member States and studying by importers from third countries the opportunities of importing goods to EU customs territory.

The increase in liberalization of the world commodity markets and strengthening the role of the WTO and positions of integration associations in the world trade are the main trends in the development of foreign trade regulation in the European Union [4, p. 166]. Tariff regulation provides for EU producers the opportunities to compete equally with imported goods on EU domestic market, and for foreign producers - to compete with domestic ones. The regulatory function of the tariff is evident through tariff quotas, suspensions, tariff preferences. Their overall goal is to stimulate competition, strengthen certain sectors of industry, in particular, stimulate employment, modernize the production etc.

Tariff rate quotas (TRQs) for a certain volume of goods are used within the framework of trade agreements concluded by the EU with third countries, as well as autonomous preferential agreements. In particular, the tariff quotas are established by the EU-Ukraine Association Agreement for Ukrainian agricultural products.

Suspensions, like tariff quotas, are an exception to normal tariff practices. During the period of validity of the measure and for an unlimited quantity they permit the total (total suspension) or partial waiver (partial suspension) of the normal duties applicable to imported goods (excluding antidumping duties) [5].

To date, the following suspensions exist in the EU: industrial (provide an opportunity for EU enterprises to import raw materials, semi-finished products and components without paying the normal duties provided for by the Common Customs Tariff, which should promote EU countries economy development); aviation (provide for suspension of autonomous duties of the Common Customs Tariff for parts, components and other goods used in aircraft construction, repair and maintenance); military (aimed at increasing the EU countries military security and strengthening the market position of European defense enterprises. Military suspensions are applies to armaments and military equipment); for outermost regions (provide for the duty-free import of certain goods of particular interest to the outermost regions of the EU taking into account their remoteness, insularity, small size, economic dependence on a few products, etc.)

Tariff preferences in the EU are applied to individual cases when exemptions from import and export duties are required while goods are freely traded in the EU or exported from the EU. Generalized tariff preferences are the abolition of customs duties on goods entering the EU market from the most vulnerable developing countries (African, Caribbean, Pacific group of states). In such a way the EU helps these countries in overcoming poverty and creating new jobs [6].
USA. The United States foreign economic activity regulation consists of a complex network of different regulatory and policy objectives. They are interconnected and mutually reinforce each other. Foreign economic activity regulation in United States corresponds to the foreign and domestic policy of the state that takes into account many political, economic and social issues. In the context of global instability and growing trend of regionalization, it is especially important for the United States to balance the goals in international trade and national security, while these goals are often contradictory.

The United States foreign trade policy consists of an infinite number of pressure points and is constrained by domestic laws and international obligations. It is filled with inconsistencies and shortcomings [7]. The government seeks to facilitate and accelerate the flow of international goods and services while maintaining national security and ensuring compliance with all relevant laws and regulations. The task of regulation is to protect of domestic industries and jobs from unfair trade practices.

All goods imported into the United States are subject to duty or duty-free depending on their classification in accordance with the applicable positions in Harmonized Tariff Schedule of the United States (HTS). The HTS is based on the international Harmonized System, which is the global system of nomenclature applied to most world trade in goods [8]. For dutiable goods, ad valorem, specific or compound rates are used.

Import duties may also vary depending on the country of origin. Most merchandise is dutiable under the most favoured nation - now referred to as normal trade relations [9]. Goods from many countries are exempt from duty under various trade agreements; duty-free status is available under various exemptions, listed in HTS. Until recently, the United States applied a Customs tariff that was among the lowest in the world: $3 \%$ on average. However, with increased tariffs on Chinese goods, as of May 2019, the US has the highest tariff rate among all developed nations [10].

Tariff rate quotas (TRQs) in United States provide importing a certain amount of product at a reduced duty rate for a certain period. There are no restrictions on the amount of product that can be entered during the quota period, but the amount entered in excess of the quota for this period is subject to higher duty rates.

The United States has entered into a series of unilateral, bilateral, regional and multilateral preferential trade agreements. For now, the United States has implemented 14 trade agreements with a total of 20 countries [11]. Under these agreements the United States ensures compliance with a number of trade restrictions and performs other traderelated functions.

China. China is an active supporter of international trade. Being the world's second largest economy, China is the world's leading merchandise exporter (see Table 1), and a significant part of Chinese industry is focused on exports. In this regard, exporters are actively supported by the government. As a WTO member, China advocates free trade, open economy and active integration into the global economy, supporting free trade agreements. This sets the 
strategic priorities for foreign economic activity regulation in China.

After becoming the WTO member, China has gradually reduced administrative barriers to trade and liberalized its foreign trade system. According to the WTO, China's average applied Most Favoured Nation (MFN) tariff rate has been progressively lowered from $15.3 \%$ in 2001 to $9.8 \%$ in 2017. The average tariff for agricultural products was $15.6 \%$, while that for non-agricultural products was $8.8 \%$ [9]. From July 1, 2018 tariffs on daily consumer goods import including 1449 tariff lines were reduced.

China charges tariffs on most imports, primarily ad valorem. Reduced import tariff rates may be applied to certain products imported from countries having Free Trade Agreements with China. Under the Closer Economic Partnership Arrangement with Hong Kong and Macau, zero tariff rates are applied to imported commodities fulfilling origin requirements from Hong Kong and Macau SARs. Hong Kong service suppliers enjoy preferential treatment in the mainland market in various service areas. Tariff rate quotas (TRQs) in China are applied to several agricultural products import such as wheat, corn, rice etc. Imported goods, that may pose a threat to fair competition for Chinese manufacturers, may be subject to antidumping and countervailing duties.

To date, China has concluded 17 Free Trade Agreements (FTAs) with 24 countries or regions, while 13 FTAs are in negotiation and another 10 are under consideration. China is a party to the Asia-Pacific Trade Agreement 1975, which is a preferential trade agreement between Bangladesh, China, India, Laos, South Korea and Sri Lanka [12].

Japan. The tariff in Japan is on average one of the lowest in the world, about $2 \%$ for non-agricultural products. But, although tariffs are usually low, in Japan there are some barriers that prevent the import of foreign goods into the country: technical standards unique to Japan, requirements for prior experience, regulations in favour of local products etc. [9]. Tariffs are based on the Harmonized System, most duties are ad valorem.

Japan has signed Agreement on Information Technologies of the WTO, which agreed to cancel tariffs on most information technology products. Japan provides preferential treatment to a WTO member countries and countries that have a bilateral agreement with Japan. Generalised preferences are granted to developing countries.

In addition to customs duties, a wide range of goods and services is subject to a consumption tax of $8 \%$. Additional taxes are levied on imported alcoholic and tobacco products.

Japan has concluded 15 free trade agreement (FTAs) and economic partnership agreement with different countries. Negotiations are ongoing between the European Union (EU) and Japan for a comprehensive Free Trade Agreement. Economic partnership agreement with ASEAN has been effective since 2008

South Korea. Korea applies the customs tariff, which is one of the lowest in the world (average 8\%). Korea also supports a tariff quota (TRQs) system designed to stabilize domestic commodity markets. Customs duties can be adjusted every six months, within the base rate, plus or minus 40 percent [9]. Korea has a fixed 10 percent value added tax (VAT) on all imports and domestically produced goods. A special import excise duty of $10-20 \%$ is also charged on the import of certain luxury and durable goods.

Korea has free trade agreements with ASEAN, the EU and European Free Trade Association, Australia, Canada, the United States etc.

\section{Financial and Credit Regulations}

Financial methods of foreign economic activity regulation are considered to be one of the most effective when it comes to export promotion [13, p. 155]. Such instruments of financial regulation as export subsidies, export credits, and instruments of export insurance are used to varying degrees in the countries analyzed. The state in this case acts as a creditor, guarantor, and donor. At the same time, the key role in the system of national export support is played by specialized financial organizations - export credit agencies.

The role of export subsidies in foreign economic activities regulation is gradually decreasing. Thus, the WTO prohibits the direct exports subsidies and allows using various indirect forms of subsidies. The decision to eliminate farming export subsidies was taken by Trade Ministers in December 2015 during the $10^{\text {th }}$ WTO Ministerial Conference in Nairobi, Kenya. So, the subsidies on agricultural products widely used in the EU and the United States before, can not be used any more. However, in the USA there is the Dairy Export Incentive Program, which pays cash subsidies to dairy exporters.

State export insurance protects exporters from financial losses and, moreover, allows commercial banks to provide them with a loan on preferential terms. National state export insurance has various organizational forms depending on general economic policy of the government, direct participation of the state in economic life, characteristics of the national insurance system etc. [14, p. 37].

Export credits on favourable terms with the state participation reduce the cost and stabilize the financing of export supplies which allows to increase their competitiveness. Particular attention is paid to improving the conditions of long-term crediting of exporters.

The most important state institutions that provide financial support to national exporters of their countries are:

- in the USA - The Export-Import Bank of the United States (loan, guarantee and insurance programs);

- in the UK - Export Credits Guarantee Department UK Export Finance (providing exporters with the opportunity to insure their export credits, guaranteeing repayment to British banks that have granted loans to exporters for a period of two years or more);

- in Germany - KFW Kreditanstalt für Wiederaufbau (export and project financing of small and medium businesses), Euler Hermes Kreditversicherungs-AG (export credit insurance);

- in Japan - Japan Bank for International Cooperation (crediting exporters and Japanese investors abroad), 
Nippon Export \& Investment Insurance (insurance of export credits, export deliveries, etc.);

- in Korea - Korea Trade-Investment Promotion Agency KOTRA (overseas market surveys, export promotion, trade info services, government-togovernment export, foreign investment in Korea promotion and business matchmaking);

- in China - the Export-Import Bank of China (crediting of foreign trade operations, state programs of preferential financing, bank guarantees, domestic and international payments), China Export and Credit Insurance Corporation (export insurance), The China Development Bank (CDB) (crediting domestic exporters).

In addition to methods mentioned above, which form the basis of financial regulation of foreign economic activity in the countries analyzed, methods and tools of tax and currency regulation of foreign economic activity are also used. They provide for tax procedures simplification and currency legislation requirements liberalization depending on current economic conjuncture.

\section{CONCLUSIONS}

In a market economy the competitive struggle acquires a global character, therefore the state cannot ignore its obligations to support the competitiveness of domestic producers and the national economy as a whole. In developed countries foreign economic activity regulation is an important part of foreign economic policy of the state. The scientific novelty of the study is that the experience of top trading countries in foreign economic activity state regulation is presented in terms of using the elements of the financial mechanism, i.e. its methods and instruments. Analyzing the methods of foreign economic activity regulation one can see that it is economic and financial methods that are preferred for using by countries in international trade, and it is quite consistent with WTO recommendations. Besides, the financial mechanisms used by countries for foreign trade regulation fit into the international context by harmonizing their national legislation with WTO norms. Among the financial methods of foreign trade regulation the tariff regulations are most comprehensively used and legally well-developed. In the countries analyzed the tariff rates on average are quite low, which helps to stimulate competition and economic growth. For some groups of goods, generally agricultural products, the system of tariff rate quotas is actively used as an instrument of additional protection for the domestic markets. Financial and credit regulations are associated mostly with export promotion. The financial support mechanism allows national exporters of goods and services to compete more effectively in the global market as well as to reduce their costs and fiscal payments. Besides, an organizational network of export financial support is well developed in the countries analyzed. The instruments of foreign economic activity regulation applied by the countries depend greatly on signing various trade agreements, integration priorities of the countries and global economic trends. Studying the experience of applying financial mechanisms for foreign economic activity regulation in economically developed countries which are leaders in international trade is of particular interest because it allows to improve the national system of state economic regulation based on the use of effective international practices.

\section{REFERENCES}

[1] World Trade Organization. World Trade Statistical Review, 2018. [Online]. Available: https://www.wto.org/english/res_e/statis_e/ wts2018_e/wts2018_e.pdf. Accessed on: June 18, 2019.

[2] Consolidated Version of the Treaty on the Functioning of the European Union, 2012. [Online]. Available: https://eurlex.europa.eu/legal-content/EN/TXT/PDF/?uri=CELEX:12012E/TXT \&from=EN. Accessed on: June 20, 2019.

[3] European Commission. TARIC. [Online]. Available: https://ec.europa.eu/taxation_customs/business/calculation-customsduties/what-is-common-customs-tariff/taric_en. Accessed on: June 18, 2019.

[4] N.V. Prytula, "Instruments of foreign trade policy of the European Union", Economics: Time Realities. Scientific Journal, no. 2(18), pp. 162-166, 2015. [Online]. Available: http://economics.opu.ua/files/ archive/2015/No2/162-166.pdf. Accessed on: June 18, 2019.

[5] European Commission. Suspensions. [Online]. Available: https://ec.europa.eu/taxation_customs/business/calculation-customsduties/what-is-common-customs-tariff/suspensions_en. Accessed on: June 18, 2019.

[6] European Commission. Generalised Scheme of Preferences (GSP). [Online]. Available: http://ec.europa.eu/trade/policy/countries-andregions/development/generalised-scheme-of-preferences/. Accessed on: June 18, 2019.

[7] Stephen D. Cohen, Joel R. Paul, and Robert A. Blecker, Fundamentals of U.S. foreign trade policy: economics, politics, laws, and issues. Routledge, 2019. [Online]. Available: https://books.google.com.ua/books?id=2AScDwAAQBAJ\&hl=ru\&so urce=gbs_navlinks_s. Accessed on: June 20, 2019.

[8] United States International Trade Commission. Harmonized tariff schedule of the United States (HTS). [Online]. Available: https://www.usitc.gov/glossary/term/harmonized-tariff-scheduleunited-states-hts. Accessed on: June 18, 2019.

[9] The Hong Kong Trade Development Council. Trade Regulations. [Online]. Available: http://hong-kong-economyresearch.hktdc.com/business-news/article/Small-Business-

Resources/Trade-Regulations/sbr/en/1/1X46GO1Z/1X05ASG8.htm. Accessed on: June 18, 2019

[10] Wikipedia. Customs duties in the United States. [Online]. Available: https://en.wikipedia.org/wiki/Customs_duties_in_the_United_States\# cite_note-9. Accessed on: June 18, 2019.

[11] U.S. Department of State. Existing U.S. Trade Agreements. [Online]. Available: https://www.state.gov/trade-agreements/existing-u-s-tradeagreements/. Accessed on: June 18, 2019.

[12] Thomson Reuters Practical Law. International trade in goods and services in China: overview. [Online]. Available: https://uk.practicallaw.thomsonreuters.com/w-010

1049? transitionType $=$ Default \&contextData $=($ sc. Default $) \&$ firstPage $=\mathrm{t}$ rue\&bhcp=1. Accessed on: June 20, 2019.

[13] I. N. Malyugina, "Export Support Measures in the EU and the Russian Federation", News of the Orenburg State Agrarian University, vol. 2, no. 18-1, pp. 154-158, 2008. [Online]. Available: https://cyberleninka.ru/article/n/mery-podderzhki-eksporta-v-stranahes-i-rossyiskoy-federatsii. Accessed on: June 20, 2019 (in Russian).

[14] Eurasian Economic Commission. Summary overview of measures and mechanisms to support the export of agricultural products and foodstuffs used in the member states of the Eurasian Economic Union and the leading exporting countries of agricultural products and foodstuffs. [Online]. Available: http://www.eurasiancommission.org/ ru/act/prom_i_agroprom/dep_agroprom/monitoring/Documents/\%D0 $\% 9 \mathrm{E} \% \mathrm{D} 0 \% \mathrm{~B} 1 \% \mathrm{D} 0 \% \mathrm{~B} 7 \% \mathrm{D} 0 \% \mathrm{BE} \% \mathrm{D} 1 \% 80 \% 20 \% \mathrm{D} 0 \% \mathrm{BF} \% \mathrm{D} 0 \% \mathrm{~B}$ E\%D0\%B4\%D0\%B4\%D0\%B5\%D1\%80\%D0\%B6\%D0\%BA\%D0\% B0\%20\%D1\%8D\%D0\%BA\%D1\%81\%D0\%BF\%D0\%BE\%D1\%80 $\%$ D1\%82\%D0\%B0.pdf. Accessed on: June 18, 2019 (in Russian). 